\title{
Identidade narrativa de Deus nas parábolas de Jesus
}

\author{
The narrative identity of God \\ in the parables of Jesus
}

Antonio Manzatto

\section{Resumo}

O cristianismo tem como marca fundamental a afirmação de que Deus age na história, e desta ação de Deus temos testemunhos em histórias que nos são narradas. $\mathrm{O}$ acontecimento histórico é irrepetível, mas as narrações têm a capacidade de torna-lo presente perenemente. Assim com Jesus e a consequente possibilidade de falarmos de sua identidade narrativa, ou seja, a identidade de Jesus que as narrações sobre ele nos revelam. Tais narrativas também nos falam de um Jesus narrador, que conta histórias nas quais apresenta sua compreensão de Deus e de seu Reino que ele veio inaugurar: são as parábolas. A proposta é ler tais parábolas perguntando-nos pela identidade narrativa do Deus de Jesus, ou seja, pela compreensão de Deus apresentada nas histórias que Jesus narra. Deixando Deus ser quem ele é nas histórias de Jesus, podemos perceber como o Messias compreende sua missão e o Reino de Deus que ele vem instaurar.

Palavras-chave: Parábolas. Narração. Identidade narrativa. Histórias. Cristologia.

\section{Abstract}

Christianity has its fundamental mark on the affirmation that God acts in history, and from His actions, we have testimonies in histories narrated to 
us. The historical event is unrepeatable, but the narratives have the capacity to make it perennially present. Thus, with Jesus and the consequent possibility of speaking of his narrative identity, or rather, the identity of Jesus that the narratives reveal to us. These narratives also tell us about Jesus, the storyteller, who recounts stories that present his understanding of God and His Kingdom, that He came to inaugurate: they are the parables. The purpose is to read such parables by asking about the narrative identity of the God of Jesus, or rather, by understanding God presented in the stories that Jesus narrates. By letting, God to be who he is in the stories of Jesus, we can perceive how the Messiah understands his mission and the Kingdom of God that he comes to establish.

Keywords: Parables. Narration. Narrative identity. Stories. Christology.

\section{Introdução}

A aproximação entre teologia e literatura tem proporcionado valiosos frutos em diversos ambientes e de múltiplas maneiras. Um destes frutos é a forma como textos bíblicos podem ser lidos a partir de perspectiva e instrumental literários, onde se tornam importantes as perspectivas narrativas e mesmo ficcionais. Ora, o judeu-cristianismo se caracteriza pela afirmação da ação de Deus na história. Isso é marca fundamental de sua identidade, e se a teologia afirma ser possível o discurso sobre Deus, ela o faz a partir de tal compreensão. Significa que a fé se refere a eventos fundantes para afirmar sua verdade e sua pertinência. Tais eventos são narrados exatamente porque são história, e se é verdade que a história precisa de interpretação, também é verdade que tais narrações, que já desempenham esta função interpretativa, também precisam ser interpretadas. Mais ainda, estas narrações não se referem apenas ao evento, mas àquele que age no evento, que é seu protagonista, e elas não descrevem apenas acontecimentos, mas o comportamento de quem age naqueles acontecimentos. A Revelação, acontecendo na história, nos é conhecida através de histórias narradas, e o Deus que se mostra naqueles acontecimentos, pode ser conhecido através das narrações que são feitas pela comunidade crente. Assim tem sido feito ao longo da história através de diversos procedimentos hermenêuticos, sobretudo exegéticos, acrescidos atualmente pelo instrumental de análise literária. 
Mais do que conhecer os textos, a teologia se preocupa em conhecer o Deus que se revela e é retratado naqueles textos. A teologia afirma, também, que a Revelação plena de Deus se realiza em Jesus de Nazaré, o Cristo, Filho de Deus encarnado, de quem falam os evangelhos. Com riqueza de detalhes, os textos evangélicos apresentam Jesus contando parábolas, fazendo-se narrador e, nessas narrativas, referindo-se ao Deus que ele chama de Pai. A teologia afirma poder conhecer este Deus a quem Jesus alude em suas parábolas através de procedimentos exegéticos que passam para a teologia por pontes de hermenêutica. Ricoeur, um dos grandes pensadores contemporâneos que trabalham sobre a hermenêutica, construiu o conceito de "identidade narrativa". A pergunta que se coloca é a de saber, então, se é possível buscar uma "identidade narrativa" de Deus nas narrações realizadas por Jesus de Nazaré, e se tal identidade pode ter interesse teológico ou, mais ainda, constituir-se em leitura teológica que a compreende e a afirma como integrante da fé da comunidade crente.

\section{Identidade narrativa}

Paul Ricoeur apresentou sua categoria de identidade narrativa no final de seu texto Temps et Récit, e ocupou-se do mesmo assunto em alguns artigos que escreveu na sequência ${ }^{1}$. Para ele, "a constituição da identidade narrativa, seja de uma pessoa individual, seja de uma comunidade histórica, era o lugar procurado da fusão entre história e ficção". E continua: "não se tornam as vidas humanas mais legíveis quando são interpretadas em função das histórias que as pessoas contam a seu respeito? E estas "histórias da vida" não se tornam elas, por sua vez, mais inteligíveis, quando lhes são aplicados modelos narrativos?" Por isso ele se propõe o seguinte encaminhamento de argumentação: "o conhecimento de si próprio é uma interpretação; a interpretação de si próprio, por sua vez, encontra na narrativa, entre outros signos e símbolos, uma mediação privilegiada; esta última servese tanto da história como da ficção, fazendo da história de uma vida uma história fictícia ou, se se preferir, uma ficção histórica,

\footnotetext{
${ }^{1}$ RICOEUR, P. Temps et récit III. Le temps raconté. Paris: Seuil, 1985. Depois, em 1986 Ricoeur fez uma conferência que está na base de dois artigos, ambos com o título de "Identidade Narrativa", e ambos publicados em 1988: um na revista Esprit, 7/8 (1988) pp. 295-304, e outro foi publicado na obra coletiva La narration. Quand le récit devient communication. Genebra: Labor et Fides, 1988, pp. 287-300.
} 
comparáveis às biografias dos grandes homens em que se mistura a história e a ficção"”.

Em um de seus textos autobiográficos, Gabriel Garcia Marquez afirma que "la vida no es lo que uno vivió, sino lo que recuerda, y cómo la recuerda para contarla" ${ }^{3}$. Curiosas formulações, de Ricoeur e Garcia Marquez, que vinculam a identidade vital do sujeito àquilo que dele se narra. Em um e outro pensamento está a convicção de que a narrativa define a identidade da pessoa. Isso pode ser dito do ato de leitura, onde me conheço diante do texto que leio, uma espécie de reconfiguração da situação do leitor quando se confronta com o texto que apresenta aquela narrativa. Neste caso, tratase menos de compreender o texto do que compreender-se diante do texto, que será importante para a definição da identidade do leitor, assim como as narrativas serão importantes para a definição da identidade daquele de quem se narram suas histórias de vida.

Há que se notar que não falamos da identidade do texto ou da identidade de seu autor ou narrador, mas da identidade daquele de quem se narra, de quem se diz algo, de quem se apresentam histórias de vida. Uma espécie de identidade do personagem, seja ele histórico ou de ficção. Não é simplesmente o texto, mas o que se narra no texto que define a identidade do personagem: "no es lo que uno vivió, sino lo que recuerda, y cómo la recuerda para contarla". A narração define a vida e a identidade do personagem. Isso é mais ou menos evidente no trato dos personagens de ficção, visto que sua identidade não é dada pelo autor ou pelo narrador mas pelas histórias que se narram a respeito dele. Se o personagem é bom ou mau dentro do enredo, isso não é definido pela intenção do autor ou mesmo do narrador, mas pelas narrativas que configuram seu caráter de bom ou mau, que definem sua identidade. Aquilo que se narra do sujeito é o que configura sua forma de ser, portanto sua identidade.

Isso é menos claro quando se fazem narrações a respeito de personagens históricos. Quase que existe uma identidade já pré-definida que se conhece pelos eventos históricos, e as narrativas a seu respeito visariam, apenas, a corroborar aquela identidade já afirmada. Assim, por exemplo, se pensamos em Adolf Hitler, já o definimos como um sujeito mau por sua conduta na Segunda Guerra Mundial, e as histórias narradas a seu respeito sempre

${ }^{2}$ RICOEUR, P. “L'identité narrative”. Esprit 7/8 (1988), pp. 295-304. A tradução aqui apresentada é de CORREIA, C. J. "A Identidade Narrativa e o Problema da Identidade Pessoal”. Arquipélago 7 (2000), pp. 177-194 (tradução comentada de "L'identité narrative" de Paul Ricoeur). ${ }^{3}$ GARCIA MARQUEZ, G. Vivir para contarla, Barcelona: Mondadori, 2002. 
serão confirmações de que se trata de um sujeito mau. Da mesma forma, personagens conhecidos como boas pessoas terão sempre histórias contadas a seu respeito que as retratarão como pessoas de bem. Mas o processo de contar as histórias é que define a identidade da pessoa, do personagem. Afinal, dizemos que Hitler é do mal exatamente porque as histórias contadas a seu respeito, histórias da Guerra, fazem aparecer sua maldade. O mesmo acontece com as pessoas do bem, como Madre Teresa de Calcutá, por exemplo. As identidades são definidas pelas histórias contadas a seu respeito, que não são necessariamente fabulações mas narrativas, próximas do real histórico ou mais criativas. Neste sentido, toda narração tem um referente que está na história e que se quer apresentar, comentar ou perceber através daquilo que é narrado. A leitura da narrativa exige uma hermenêutica que chegue a seu sentido mais profundo, ultrapassando sua superfície e podendo entender aquilo a que se refere. Diríamos da superação do literalismo para uma leitura que busque a compreensão de seu significado.

Aqui cabe lembrar a importância de se contarem histórias a partir do ponto de vista dos vencidos, uma realidade não tão presente na historiografia tradicional, mas que foi bastante cultivada na América Latina em termos religiosos e teológicos no período da teologia da libertação. Narrar histórias a partir do ponto de vista dos pequenos e dos pobres configura uma outra identidade a esses personagens. Afinal, a historiografia oficial costuma caracterizar como bons os vencedores, mas o outro lado da história revela que não é assim necessariamente. É extremamente importante manter viva a memória dos vencidos e preservar suas identidades pessoais, seus projetos e ideais que podem, ainda, motivar pessoas e ações na época atual.

A identidade narrativa, seguindo o conceito de Paul Ricoeur, foi categoria aplicada por Adolphe Gesché em seu estudo cristológico intitulado "Pour une identité narrative de Jésus" " . Pode-se compreender o desafio: conhecer a identidade de Jesus naquilo que os textos narram sobre ele. E Gesché ensaia com maestria a elaboração de tal construção, compreendendo que há uma intermediação realizada pelo texto evangélico entre a história de Jesus de Nazaré e a profissão de fé da Igreja, ou seja, entre o Jesus histórico e o Cristo

\footnotetext{
${ }^{4}$ GESCHÉ, A. "Pour une identité narrative de Jésus". RTL 30/2 (1999), pp. 153-179 - completado pela publicação da segunda parte do artigo no número seguinte da mesma revista: $R T L$ 30/3 (1999), pp. 336-356. Tais artigos foram por ele retomados em 2001, quando da publicação do sexto volume da coleção "Dieu por penser" (Le Christ. Paris: Cerf, 2001 - sua publicação no Brasil é de 2004).
} 
da fé. Para ele, o texto evangélico revela um Jesus que não é nem o histórico, nem aquele que a confissão de fé apresenta, fazendo com que entre a história e a doutrina exista uma passagem obrigatória pelo texto evangélico; este não é nem relato historiográfico, nem compêndio de doutrina teológica, mas uma obra de narração que realça uma intriga, um enredo, exatamente como o faz qualquer obra literária. Gesché $e^{5}$ procura ressaltar que esta intermediação é voluntária e, de certa forma, definidora e constitutiva da configuração da identidade de Jesus. É mais que uma ponte que liga dois elementos importantes, a figura histórica e a doutrinal. Há, pelo texto, a construção e afirmação de uma identidade específica de Jesus que chamamos de identidade narrativa. Ela é diferente de sua eventual identidade histórica porque é posterior aos eventos históricos. As narrativas de histórias a respeito de Jesus aparecem depois de sua existência histórica, ao menos nos textos que conhecemos. Sua identidade narrativa não é continuação da história de Jesus, agora apresentada em relatos; existem, é verdade, variadas maneiras de se contar a história de um personagem, e no caso isso aparece no número plural de evangelhos que a Igreja conhece. A definição da identidade responde à questão "quem"?, que, no pensamento de Ricoeur, só poderá ser respondida pela narrativa, e a tradição teológica da Igreja sempre entendeu que os textos evangélicos visavam levar o leitor a responder àquela pergunta: "quem dizem os homens que eu sou?" (Mc 8,27). Esta pergunta é, dizem todos os especialistas, central no evangelho de Marcos, por exemplo, e não é por acidente que ela figura exatamente no meio da obra.

É verdade que podemos acrescentar à reflexão de Gesché que o texto narrativo possui elementos de história, mesmo que não seja um relato historiográfico. Afinal, nenhum texto é impermeável à história, assim como também não o é a elementos teológicos que antecedem sua elaboração. A narrativa sobre Jesus não é um texto doutrinal, certo, mas encaminha para a reflexão teológica e a formulação doutrinal que se fará na sequência, constituindo uma ponte entre os eventos de sua história e a proclamação da fé da Igreja. Mesmo que apresente reflexões teológicas e elaborações doutrinais apenas na sequência, já são portadoras de uma experiência de fé, e é possível perceber que já existem elementos de teologia que ajudam em sua estruturação. Os relatos sobre Jesus não são historiografia pura, nem simples obra completa de ficção; não é texto doutrinal, mas já inclui elementos de teologia. Dizemos, então, que sua elaboração não é estritamente teológica

\footnotetext{
${ }^{5}$ Veja-se com proveito a compreensão de exegese literária apresentada por GESCHÉ, A. $O$ Cristo. Coleção Deus para pensar VI. São Paulo: Paulinas, 2004, especialmente pp. 112-113.
} 
nem histórica, mas narrativa, ou seja, literária. O autor não pensa uma teologia e depois a preenche criptograficamente com narrativas sobre Jesus, como se os textos evangélicos não fossem mais que teologia cifrada; também não dá conta apenas da sequência histórica de acontecimentos que compuseram a vida de Jesus, como se fosse um relato jornalístico. A elaboração narrativa dos evangelhos segue o princípio de contar uma história de maneira atraente e com coerência, e por isso, indiscutivelmente, visa o leitor. Não apenas o leitor imediato da comunidade que compõe o texto, mas simplesmente "o leitor", que tomará contato com o texto em não importa qual período histórico, e procurará responder à questão da identidade do personagem da narração: "quem é ele?", ou "quem dizeis que eu sou?"

Vale notar que no início do cristianismo em primeiro lugar foi proclamado o querigma, o anúncio da fé que proclamava Jesus de Nazaré como o Messias. A esta proclamação se seguiu não uma elaboração dogmática ou doutrinal mais sistematizada, mas sim o estabelecimento de narrações ${ }^{6}$ a respeito de Jesus, como para dizer que a proclamação de fé da comunidade se baseava em sua história, ou dito de outra forma, que sua identidade se encontrava nas histórias que se contavam a seu respeito. À pergunta “quem é Jesus?”, não se respondia com uma afirmação dogmática, mas com narrativas que, de um lado, afirmavam sua identidade e, de outro lado, buscavam suscitar nos ouvintes um posicionamento que lhes permitisse dar o passo da fé. Assim se estabeleceram as histórias a respeito de Jesus, narrando-o e, por este caminho, afirmando sua identidade messiânica: "Jesus fez ainda, diante de seus discípulos, muitos outros sinais, que não se acham escritos neste livro. Esses, porém, foram escritos para crerdes que Jesus é o Cristo, o Filho de Deus, e para que, crendo, tenhais vida em seu nome" (Jo 20,30-31).

\section{Jesus narrador}

É curioso notar que os textos evangélicos não apenas narram Jesus, mas também o apresentam como narrador. Claro que isso aparece nos ditos e sermões de Jesus onde ele é apresentado como o autor dos discursos, mas também em narrativas de ficção, as parábolas de Jesus. Ali ele assume a função de narrador de histórias, elaborando enredos que visam não apenas chamar a atenção, mas levar seus ouvintes à reflexão. As parábolas são, sim, histórias com uma

${ }^{6}$ Paul Ricoeur fala exatamente dessa passagem do querigma à narração em RICOEUR, P. $A$ hermenêutica bíblica. São Paulo: Loyola, 2006. 
"moral", um sentido mas, como toda metáfora, seu sentido permanece aberto e cabe ao leitor, no caso o ouvinte, interpretá-la, compreendê-la, conhecer-se perante ela. Olhar as histórias em que Jesus aparece como narrador não apenas nos ajuda a definir ou compreender sua identidade messiânica, mas também, e talvez sobretudo, a identidade dos personagens sobre quem ele conta tais histórias. Assim como as narrativas sobre ele nos ajudam a compreender e definir sua identidade, ao menos sua identidade narrativa, assim também suas parábolas são narrativas que nos possibilitam compreender e definir a identidade narrativa daqueles sobre quem se narram as parábolas, ou daquilo sobre o que falam as parábolas, ou seja, Deus e o seu Reino.

É consenso entre os historiadores que a narrativa de parábolas é ação do próprio Jesus de Nazaré, o Jesus da história ${ }^{7}$. O personagem literário também se apresenta como narrador por obrigação de fidelidade à história, ou seja, estas pequenas obras de ficção narrativa fazem parte da dinâmica pedagógica daquele judeu que viveu na Palestina do século I, foi aclamado como Messias por seus seguidores e mudou a história do mundo. A confirmação do fato se dá de maneira espantosa, porque apenas o Evangelho de João não apresenta relatos de parábolas. Se o Evangelho de Marcos apresenta um número pequeno de parábolas, o material de Mateus é mais numeroso e o de Lucas é particularmente rico. Acrescente-se que a chamada Fonte Q também conhece parábolas, assim como alguns evangelhos apócrifos, como o de Tomé, o de Tiago e o dos Hebreus. Desta forma, a tradição sinótica e apócrifa conhece, sim, relatos em que Jesus aparece como narrador, e sua ausência em outros textos cristãos antigos, como os paulinos ou joaninos, atestam o valor histórico da prática de narrar parábolas ${ }^{8}$. Desta forma, o pregador galileu que percorreu as aldeias e vilas da Palestina foi um criador de relatos de ficção que possuem ainda certo charme estético, e que foram elaborados como forma de proclamação de sua mensagem, incluindo ameaças proféticas, proclamações apocalípticas e máximas de caráter sapiencial e ético. Jesus foi um autor talentoso na criação destes pequenos relatos, verdadeiro poeta do cotidiano.

Se o número de parábolas que conhecemos e que podem remontar a Jesus é bastante variável, entre trinta e setenta, a imensa maioria delas, se não todas, versam direta ou indiretamente sobre Deus e o Reino de Deus,

${ }^{7}$ Assim JEREMIAS, J. As parábolas de Jesus. São Paulo: Paulus, 2016; também PAGOLA, J. A. Jesus, uma aproximação histórica. Petrópolis: Vozes, 2010.

${ }^{8}$ Cf. BARBAGLiO, G. Jesus, hebreu da Galileia. São Paulo: Paulinas, 2011, especialmente p. 311. 
e por isso constituem elementos indispensáveis para a compreensão de sua mensagem. Ou seja, como os Evangelhos não apresentam um relato sistemático da ideia que Jesus tem sobre Deus ou sobre o Reino, mas apenas indicativos fragmentários, as parábolas são elemento importante para que se compreenda o que ele afirma quando diz Deus ou Reino de Deus. Em outras palavras, onde Jesus mesmo é quem narra, seja tanto o personagem histórico como o literário, suas narrativas, as parábolas, constituem terreno no qual se pode buscar a "identidade narrativa" de Deus ou do Reino de Deus que os Evangelhos apresentam.

\subsection{As parábolas}

Já os textos evangélicos arriscam a interpretação de algumas parábolas de Jesus, seja no estilo de assemelhá-las a alegorias, seja no sentido de atribuirlhes certa obscuridade: "aos discípulos Jesus falava abertamente, mas aos de fora, falava em parábolas" (Mc 4,11). Também não hesitaram em introduzir em algumas destas parábolas uma clara aplicação metafórica a Deus ou a seu Cristo. O enquadramento redacional das parábolas também tem certo interesse porque encaminha, de alguma maneira, sua leitura: parábolas inseridas no contexto da confrontação entre Jesus e os chefes do judaísmo indicam, na prática, a direção da paixão de Jesus e a condenação de seus executores (Mc 11); as chamadas parábolas de misericórdia (Lc 15) estão inseridas em contexto onde sobressai a solidariedade de Jesus para com os pecadores excluídos. De maneira geral, já no início, a comunidade crente entendeu as parábolas de Jesus como parábolas sobre Jesus ${ }^{9}$. A interpretação recente aproxima a interpretação das parábolas da noção de metáfora constituída por uma narração que representa o que seja o Reino de Deus. Assim, há um sujeito (o Reino), um verbo (é, como se fosse) e um predicado (a história que se narra). O Reino não é literalmente aquilo que é narrado, mas é seu referente. Desta forma, as parábolas de Jesus se inserem naturalmente em sua pregação, no sentido de que falam daquilo que ele anuncia também de outras formas, por seus discursos, palavras e comportamentos. Afinal, as parábolas são narrativas de ficção, ou seja, criações artísticas que apresentam plasticamente uma outra história, a da ação de Deus que instaura desde já o seu Reino, e por isso são

\footnotetext{
${ }^{9}$ Seguimos de perto aqui BARBAGLIO, G. Jesus, hebreu da Galileia. São Paulo: Paulinas, 2011.
} 
constitutivas da pregação de Jesus e devedoras de sua compreensão de Deus e de sua função de anunciador e instaurador do Reino de Deus ${ }^{10}$.

Do ponto de vista da composição narrativa, as parábolas versam sobre situações do cotidiano e por isso falam de plantações, de trabalhadores, sejam eles simples operários do campo ou da cidade, ou governantes; falam de homens e mulheres, de famílias, de refeições, da casa e de seus bens, de casamentos ou de comportamentos religiosos. Já os personagens, protagonistas das profissões e comportamentos retratados nas histórias, podem ser únicos ou múltiplos, como o semeador ou os trabalhadores da última hora. Algumas vezes, por conta da multiplicidade de personagens, o enredo se torna bastante complexo, como nas parábolas do joio e do trigo ou na história do filho pródigo. Os sentimentos dos personagens ou suas emoções, por vezes, também são determinantes para o enredo da história, como a alegria de encontrar o tesouro ou a moeda perdida, ou então a cólera do rei que manda incendiar cidades ou prender o funcionário malvado. Estas histórias, com seus enredos, temas e personagens, algumas vezes são interpelativas no sentido de que Jesus pede a seus ouvintes um posicionamento, em uma espécie de artifício narrativo que procura envolver aqueles que escutam a narração e confirmando uma espécie de característica argumentativa da história: assim o "quem dentre vós", ou o "que vos parece?". Por tratar-se de um relato parabólico, a posição que o ouvinte assume com relação àquela história narrada é, imediatamente, aplicada à outra história, aquela à qual remete a parábola, seja a afirmação de comportamento religioso, seja a afirmação sobre o comportamento de Deus ou a natureza de seu Reino. Trata-se da forma pela qual o narrador, no caso Jesus, defende sua posição diante de outras diferentes ou opostas que, não raro, lhe são apresentadas de maneira acusatória. $\mathrm{O}$ pretendido pelo narrador é fazer uma transição de sentido entre o fictício e o real, entre situações do cotidiano humano e a forma da ação de Deus. Por isso é que podemos perguntar, nos relatos de parábolas, sobre a "identidade narrativa" de Deus e de seu Reino. Claro que há que considerar que a apresentação de Jesus como narrador se faz dentro de uma narração sobre ele. Suas parábolas não são textos seus que nos chegaram, mas há um texto maior que narra o que Jesus teria narrado. De certa forma, isso limita o que se pode dizer da "identidade narrativa" do que aparece nas parábolas, e que estaria de alguma forma relacionado à identidade narrativa

\footnotetext{
${ }^{10}$ Além de BARBAGLIO, G. op. cit., veja-se também JEREMIAS, J. As parábolas de Jesus. São Paulo: Paulus, 2016; ainda PAGOLA, J. A. Jesus, aproximação histórica. Petrópolis: Vozes, 2010.
} 
de Jesus dentro dos evangelhos. Por isso o conceito de "identidade narrativa" ao se ler as parábolas é, de certa forma, também parabólico, mas vale o risco da interpretação ainda que sob cuidados hermenêuticos necessários ${ }^{11}$.

\subsection{Identidade narrativa do Deus de Jesus}

A passagem do fictício ao real, ou seja, a compreensão das parábolas de Jesus em termos de histórias sobre o Deus de Jesus, obedecem necessariamente a dois elementos: a estrutura ao menos temática das narrativas e sua contextualização no ministério de Jesus. Neste sentido, a identidade narrativa de Deus estará relacionada à definição da identidade narrativa de Jesus. Tal identidade, no entender de Gesché, refere-se à messianidade de Jesus, ou seja, nas narrativas evangélicas ele é identificado como o Messias, aquele que é enviado por Deus para estabelecer o seu Reino ${ }^{12}$. As parábolas como que cristalizam uma teologia narrativa de Jesus ${ }^{13}$, ainda que sua compreensão esteja enquadrada pelos procedimentos narrativos e redacionais dos autores dos textos evangélicos. Por isso as parábolas falam, também, de Jesus e contribuem para a afirmação de sua identidade narrativa na medida em que ele se configura como o enviado daquele Deus a quem suas parábolas se referem.

Nas narrativas parabólicas de Jesus sobressaem algumas características do Deus em quem ele crê, e por isso constituem o que chamamos aqui de "identidade narrativa" do Deus de Jesus. A primeira destas características, indiscutivelmente, é que se trata do Deus do Reino. Ou seja, não apenas a ideia de Deus manifesta o quê e como seja o seu Reino, mas também, inversamente, a ideia de Reino manifesta a identidade do Deus que o sustenta, pois de um lado trata-se do Reino de Deus, e de outro trata-se do Deus do Reino. As parábolas apresentam este Reino como dom e como graça que é preciso reconhecer no tempo oportuno, o tempo de agora, mas que é um oferecimento de Deus a ser acolhido com alegria e sem outras maiores exigências. A alegria maior

\footnotetext{
${ }^{11}$ Estou aqui dizendo que, se é possível definir a identidade narrativa de Jesus a partir dos evangelhos que são narrativas sobre ele, a definição da "identidade narrativa" de Deus e de seu Reino nas parábolas de Jesus precisa ser vista de forma relativa a essa identidade de Jesus, uma vez que são os evangelhos que o apresentam narrando suas pequenas histórias. O procedimento é semelhante, mas não é exatamente o mesmo.

${ }^{12}$ Assim em GESCHÉ, A. O Cristo. Coleção Deus para pensar VI. São Paulo: Paulinas, 2004; veja-se também MANZATTO, A. "O Messias do texto". Ciberteologia 36 (2011), pp. 5-22.

${ }^{13}$ ARENS, E. "Metaphorische Erzählungen und komunikative Handlungen Jesu". BZ 32 (1998), p. 63, apud BARBAGLIO, G. op. cit., p. 338.
} 
é a de Deus que oferece seu Reino às pessoas, no sentido de que há maior alegria em dar do que em receber (At 20,35). À alegria de Deus se refere a alegria de seu Cristo e dos que aceitam participar do Reino, simbolizado em um banquete de festa no qual a participação, se é livre, implica em aceitação e disposição de fraternidade. Várias parábolas se referem ao Reino de Deus e nelas se ressalta a alegria de quem oferece e com a qual este oferecimento é recebido. As parábolas do tesouro e da pérola, por exemplo, e mais ainda a da moeda e da ovelha perdidas, assim como a do filho pródigo, todas vão na linha de afirmar a alegria do Reino de Deus, alegria motivada pela salvação realizada por Deus e pela fraternidade acontecendo entre os seres humanos.

Na mesma direção, e como seu complemento, se encontra a preferência pelos excluídos a quem é oferecido o Reino de Deus, os seus destinatários primeiros. Jesus justifica seu comportamento para com os pecadores apontando para o comportamento de Deus, como transparece nas parábolas de Lc 15. A cristologia do narrador evangélico corresponde à teologia do narrador das parábolas. Para dizer de outro modo, Deus se comporta com relação aos excluídos da mesma maneira como Jesus o faz, eis o que é destacado nas narrativas destas parábolas. Não é de se estranhar, portanto, que a teologia desde muito cedo afirme que em Jesus está a Revelação plena de Deus, porque, segundo ele mesmo, Deus age como ele o faz. Na verdade, é a ação misericordiosa de Deus, a que remetem as parábolas da moeda, do filho ou da ovelha perdida, que se historicizam no comportamento de Jesus. Assim, se pode dizer que Deus age em Jesus e por isso ele proclama "a hora da grande e definitiva reviravolta da história causada pelo poder libertador e salvador de Deus rei"14. Note-se, por isso, que o acento das duas primeiras parábolas de Lc 15 está na busca e na alegria do encontro, como acentua Barbaglio. $\mathrm{O}$ acento não está no comportamento do pecador que encontra o bom caminho, mas no Deus que tudo faz para buscar o que está perdido e se alegra com o reencontro. Deus é o sujeito da ação, não o pecador. O que as parábolas narram não é nenhum processo de conversão, incluída aí a narrativa do filho pródigo que retorna à casa do pai por absoluta necessidade material, já que o faz para conseguir emprego, não para reencontrar o bom caminho. É o pai quem age e torna-se o sujeito da acolhida do filho. E então a parábola não retrata mais as emoções do filho que volta, mas apenas a alegria do pai e de toda a casa, e a cólera do irmão mais velho. Também vale ressaltar que nas parábolas da ovelha e da moeda perdidas, o pastor e a mulher se colocam

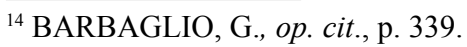


em contínuo estado de busca, sem desistir. Trata-se de insistência na busca que só termina quando acontece o encontro que resulta em alegria.

Nestas parábolas o Deus de Jesus busca os excluídos porque, sem sua ação, para eles seria a morte. Assim diz o pai com relação ao filho que volta: ele estava morto e voltou à vida. Ultrapassa-se o simples limite da moral para colocar um valor mais fundamental, a vida dos pequenos e fracos. Em todo o ministério de Jesus transparece exatamente esta sua preocupação para com os excluídos, de quem ele se mostra solidário e a quem ele quer reinserir na comunidade, ou seja, na possibilidade de vida. Daí a alegria do encontro, pois é um prodígio que deve ser festejado esta "volta à vida". A alegria divina não se resume a simples sentimento, mas se concretiza em uma celebração comunional. A mulher que encontra a moeda chama as amigas para festejar; $o$ pastor se alegra com o reencontro da ovelha, e o pai faz uma grande festa para celebrar a volta do filho. A inclusão dos excluídos marca a alegria do Reino e sua nova ordem, na qual não cabe a ira do irmão mais velho que se recusa a fazer festa com seu irmão. É verdade que a parábola termina com a possibilidade de vários epílogos, porque não se diz se o irmão mais velho entrou para a festa, ou foi-se embora, ou resolveu sair de casa. Os ouvintes devem preencher este epílogo, e fazê-lo existencialmente pela participação no Reino anunciado por Jesus e pela aceitação do Deus que prefere os excluídos e necessitados ${ }^{15}$.

A parábola mateana sobre os trabalhadores da última hora (Mt 20,1-16) mostra o mesmo fato sob outro aspecto. O protagonista inconteste da parábola é o patrão, e o relato parece ser sobre a relação entre trabalho e salário, com o confronto entre quem trabalhou todo o tempo e quem o fez uma única hora. Para obter o efeito desejado, não se fala do valor do salário, apenas que foi pago o combinado com quem trabalhou desde cedo e os demais recebem o mesmo. O cume da narrativa é o momento do pagamento, em que se começa pelos últimos criando expectativa maior nos primeiros. A igualdade do pagamento provoca contestação, mas o patrão afirma que não cometeu injustiça pois cumpriu o acordo. Ora, independentemente dos destinatários do relato de Jesus, parece evidente que o que se destaca é a bondade do patrão para com os que trabalharam por último e conheceram toda a angústia da espera

\footnotetext{
${ }^{15}$ BARBAGLIO, G. op. cit, faz notar (p. 343) que as parábolas indicam a aceitação dos pecadores sem que se lhes peça nem conversão, nem ritos penitenciais. Isso provoca a ira dos representantes da religião oficial, que contestam Jesus em nome de um Deus que prefere os bons e puros. A pregação de Jesus e a recusa que provocou estão estampados no relato destas parábolas, como de resto também em seu ministério.
} 
por um trabalho necessário para sustentar suas famílias. A falta de trabalho significaria fome, e a preferência de Deus pelos pequenos aparece ainda uma vez porque a eles se paga o necessário para sobreviverem. Trata-se de bondade e graça por parte de Deus, que acolhe pecadores sem diminuir-lhes a paga e proclama a justiça da igualdade fundamental entre todos os seres humanos mostrando a efetiva reviravolta que o estabelecimento do Reino de Deus provoca. O mesmo acontece na parábola dos convidados ao banquete (Lc 14,1524 e Mt 22,1-14), convite recusado pelos convidados de honra e entregue então a pessoas de todo tipo, estropiados ou pagãos. O relato que versa sobre a substituição de uns por outros, na verdade enfoca a gratuidade da comensalidade preparada pelo rei, que traz para o banquete os párias, gente ignorante da Lei e mesmo pecadores. No contraste entre os privilegiados e os excluídos, são os últimos que participam do banquete porque os primeiros recusaram a oferta. O relato do bom samaritano (Lc 10, 25-37) também evoca a condição da preferência pelos excluídos, seja aquele que foi atacado pelos ladrões, seja o próprio samaritano que, por ser quem é, já é colocado fora da possibilidade de relação com Deus. O relato de Jesus mostra que é em seu comportamento, e não no dos religiosos exemplares, que se encontra o jeito de ser de Deus.

Algumas parábolas versam diretamente sobre o Reino de Deus e o reconhecimento dos sinais de sua chegada, através exatamente do ministério de Jesus que o instaura. Talvez se pudesse pensar que tais parábolas não apresentam a predileção pelos excluídos e que assim falariam de outras coisas ou, para utilizar a linguagem anterior, dariam uma outra identidade narrativa ao Deus de Jesus. Ocorre que as parábolas, como dissemos, se situam no ministério de Jesus, e isso inclusive do ponto de vista histórico. É dentro deste quadro que elas precisam ser interpretadas, pois assim se terá mais claro como elas se ligam à ação de Jesus e formam o quadro no qual se pode, sim, compreender a identidade narrativa de Deus.

Dois pontos precisam ser afirmados. O primeiro é sobre a compreensão de Reino de Deus, e o segundo sobre a messianidade de Jesus. Muito rapidamente, podemos dizer que o Reino de Deus é outra forma de viver a organização da sociedade, onde os excluídos terão o privilégio de serem os primeiros. Tratase de reorganizar o mundo e as relações humanas de forma a possibilitar a fraternidade, e por isso o Reino de Deus é Vida Nova, ou seja, nova forma de viver a vida, plasmada em uma Nova Aliança estabelecida entre Deus e a humanidade através do próprio Jesus, o instaurador do Reino. Seu ministério é compreendido exatamente desta maneira: ele vem para realizar o Reino 
desde já, aqui e agora. Por isso os sinais de sua chegada são, exatamente, a possiblidade de vida nova trazida pelos milagres, pelas curas, pelo perdão, pelo acolhimento, pela misericórdia. O desaparecimento das desigualdades é um sinal da chegada histórica do Reino ${ }^{16}$, e por isso as primeiras comunidades cristãs vivem em comum e disponibilizam seus bens (At 2,42-47). Não admira que a representação do Reino seja, por isso, a comensalidade vivida por Jesus, e a comunidade crente tenha guardado referência a isso no sacramento da Eucaristia. Com certeza a refeição em comum remete à vida fraterna que é a realização do Reino de Deus: Vós sois todos irmãos (Mt 23,8).

É dentro deste quadro que devem ser lidas as parábolas do Reino de Deus. Não se trata de decifrar enigmas, porque as parábolas não são necessariamente alegorias, mas metáforas que falam do Reino e querem dizer da importância de sua compreensão, do assumir suas características, de aceitá-lo e perceber como isso é a realização da vontade de Deus, já expressa, aliás, no Primeiro Testamento ${ }^{17}$. A parábola da semente que cresce sozinha, do grão de mostarda e do fermento apontam exatamente nesta direção, assim como a do joio, da rede repleta e do semeador (Mc 4,3-8). Falam do Senhorio de Deus, de seu governo do mundo e da história. E lá onde Deus governa, lá onde ele é Rei, as coisas acontecem segundo sua vontade, que precisa ser compreendida dentro da referência à identidade narrativa a que aludimos, sempre no contexto das narrações feitas por Jesus. Estas parábolas não são simplesmente afirmações do absolutismo divino, mas de seu governo que estabelece fraternidade e, por isso, se realiza em benefício dos pequenos como salvação. Elas não esquecem que o Reino que se inicia no ministério de Jesus tende a crescer e plenificarse. Tudo não se dá no aqui e agora, até porque tudo é processo ${ }^{18}$. Talvez Jesus fosse confrontado àqueles que querem não apenas sinais, mas a efetiva realização plena do Reino que ele anuncia, e a estes Jesus precisa lembrar que estamos ainda na história, em processo e a caminho, mas que seu ministério é real e verdadeiro, porque o Reino já está presente na história e não apenas se constitui como promessa futura. Já se o pode perceber, já se o pode viver, ainda que não em plenitude.

\footnotetext{
${ }^{16}$ Assim se pode entender Papa FRANCISCO, Evangelii Gaudium, Brasília: Ed. CNBB, 2013, no. 176 .

${ }^{17}$ Assim será compreendida a aliança mosaica que funda o Povo de Deus para viver em comunhão. Veja-se GRENZER, M. O projeto do Exxodo. São Paulo: Paulinas, 2004.

${ }^{18}$ Papa FRANCISCO, Evangelii Gaudium, Brasília: Ed. CNBB, 2013, no. 222-225, lembra que o tempo é superior ao espaço e, portanto, há que cuidar dos processos que se estabelecem.
} 
Daí a importância não apenas de reconhecer a função messiânica de Jesus, mas a perspectiva do tempo presente, isto é, a hora da realização do Reino. Esta é a hora, diria o Evangelho de João ${ }^{19}$. Uma série de parábolas parecem indicar a premente importância do reconhecimento deste momento de salvação oferecido por Deus e que está presente em nossa história atual. A parábola da figueira estéril (Lc 13,6-9), assim como a do administrador desonesto (Lc 16,1-8) colocam ênfase no momento decisivo, na hora propícia em que se deve reconhecer os sinais dos tempos. Afinal, é Jesus quem narra, é o enviado de Deus que diz do momento da chegada do Reino: a hora é agora (Mc $1,15)$ e é preciso reconhecê-lo. Assim também com a parábola das virgens (Mt 25,1-13) ou do amigo que bate à porta (Lc 1,5-8), e mesmo a dos vinhateiros homicidas (Mt 21,33-44) e dos dois filhos (Mt 21,26-32). Uma parábola que parece ir na contramão do que se disse é a do servo sem piedade (Mt 18,2335). Porém, há que se perceber que não se trata da imposição de exigências desmedidas, de sacrifícios ou renúncias impossíveis. Ao contrário, há o oferecimento da graça aos pequenos e pecadores, que alegremente recebem os dons e graças de Deus, seja salário, cuidado ou bens. A exigência, se podemos dizer assim, decorre daquilo que se recebeu em primeiro lugar. Não se faz exigência para receber algo, apenas se pensa que o comportamento de quem na alegria recebeu os dons, corresponda a estes dons recebidos, esparramando a mesma alegria. A parábola dos talentos (Mt 25,14-30) não está distante do mesmo sentido, pois o que se destaca não é a cólera final, mas a palavra que diz da alegria de receber e distribuir, como na comensalidade celebrada e vivida por Jesus em tantas outras situações. Exatamente neste sentido o Reino é realidade nova, é Vida Nova, e não apenas inversão das classes sociais dominantes.

\section{Conclusão}

A fé cristã proclama a realidade da ação salvadora de Deus na história, de maneira muito especial em Jesus de Nazaré. Esta proclamação querigmática é atestada, em primeiro lugar, em forma narrativa. As primeiras comunidades, exatamente as que proclamavam o querigma da messianidade de Jesus, o faziam através de narrações que remetem à sua prática de instauração do Reino de Deus. Não é senão posteriormente que as linguagens teológica e dogmática fizeram sua entrada em cena, como forma de confirmar, de maneira

${ }^{19}$ Os especialistas não deixam de referir-se à compreensão joanina da hora. Assim DE LA CALlE, F. A teologia do quarto evangelho. São Paulo: Paulinas, 1985. 
contínua, a leitura querigmática inicial. A primeira linguagem de transmissão da fé é narrativa. Paul Ricoeur, aliás, dizia que a narração é a forma mais adequada para se falar do Deus que age na história, exatamente porque a história pede histórias que a tornem permanente. Porque o evento histórico é único, irrepetível, e as narrações o fazem permanecer presente na história, exatamente porque elas possuem, em sua natureza, esta força de tornar presente aquilo ou aquele de quem se fala.

É verdade que outros gêneros literários estão presentes na Escritura, inclusive no Novo Testamento e, na elaboração dos evangelistas, mesmo colocados na boca de Jesus. Há ditos sapienciais, sermões, advertências e controvérsias, por exemplo, onde o personagem Jesus fala. No entanto, as parábolas são o gênero onde ele aparece como narrador. As narrativas pedem escuta, evidentemente; leitores, poderíamos dizer. Elas pedem quem as ouça, quem as leia, quem as interprete, quem as faça vivas. Quem as retire dos museus, dos textos, e as tornem espírito vivo, presença atual. Sim, isto se faz pela interpretação, do que aliás não se deve ter medo. Não há que querer fixar fórmulas interpretativas, porque o referencial de significado permanece aberto e é desta maneira que os textos bíblicos podem continuar sendo palavra viva para as gerações atuais, e isso é verdade também para todos os gêneros literários presentes na Escritura. A afirmação da identidade narrativa vem exatamente da compreensão da importância da Revelação. Em teologia, isto se faz para que se possibilite que Deus seja quem ele é, e não o precedamos por nossos conceitos ou pré-conceitos de ordem filosófica, ideológica ou mesmo religiosa. A Revelação exige abertura e acolhimento ao Deus que se faz presente em ambiente humano.

O estudo da identidade narrativa de Jesus a partir dos textos evangélicos vem sendo feito em diversos trabalhos, de exegese e teologia, e com bastante sucesso. Nasce da compreensão de que, nos evangelhos, Jesus é narrado, o que possibilita a afirmação de sua identidade narrativa, a confissão de sua identidade a partir das características próprias das narrações que se fazem sobre ele. O que apontamos aqui é a possibilidade de pensar a identidade narrativa de Deus a partir das narrações feitas por Jesus. Desta forma, deslocamos a compreensão de Jesus narrado para a de Jesus narrador, e a afirmação da identidade narrativa de Jesus para a identidade narrativa de Deus. Não cremos que o processo está concluído, apenas iniciado, e outros teólogos, exegetas, literatos e especialistas de diversas áreas de conhecimento podem contribuir na reflexão e no debate. 
No nosso modo de entender, as parábolas de Jesus indicam que Deus é identificado como o Deus do Reino em sua preferência pelos pequenos, os pobres, os humildes, os pecadores, os excluídos. As histórias de Jesus apontam para isso e, mais, para o Reino que ele vem instalar e que, realizado e governado por Deus, é oferecimento gratuito porque endereçado àqueles que apenas podem recebê-lo, sem dar nada em troca. É o Deus do Reino que é Pai de todos, com preferência para com os últimos, por isso é um Deus parcial. Efetivamente, só é possível ser de todos se parte dos últimos, porque do contrário estes ficarão de fora. É o Deus do perdão e da misericórdia, que propõe a novidade do recomeço, mesmo de uma nova criação, superando dominações e exclusões para estabelecer a igualdade e a fraternidade. Indiscutivelmente, o Reino é apresentado como nova sociedade porque concretizado em novas relações entre as pessoas e destas com Deus, em perspectiva do amor. Este o Reino que Jesus vem instaurar, pelo qual entrega sua vida e que realiza com sua ressurreição.

A inversão de perspectiva é notória porque estabelece novo critério para o conhecimento da Revelação de Deus, e neste sentido as parábolas de Jesus confirmam suas ações, seus discursos e comportamentos, inserindo-se na mesma lógica. Como se as narrativas feitas por Jesus exigissem outros gêneros literários que, cada um segundo sua maneira específica, confirmassem sua pregação e o sentido daquilo que apontou em suas narrativas. De certa forma, as parábolas também funcionam como uma justificativa de Jesus para seu comportamento: se Deus faz assim, então eu também faço. Daí a importância da aceitação do Reino de Deus como realidade nova, simbolizada na comensalidade e na convivialidade, e no reconhecimento de sua presença efetiva na história, o que equivale a dizer que se precisa percebê-lo no ministério de Jesus, o enviado para realiza-lo. Vendo o que Jesus faz e realiza, se percebe o que seja o Reino que ele vem instaurar. Indiscutivelmente, a identidade narrativa de Deus se relaciona com a identidade narrativa de Jesus nos evangelhos, até porque é ali que, ao mesmo tempo, ele é narrado e também apresentado como narrador.

\section{Referências bibliográficas}

ARENS, E. "Metaphorische Erzählungen und komunikative Handlungen Jesu". BZ 32 (1998), pp. 52-71.

BARBAGLIO, G. Jesus, hebreu da Galileia. São Paulo: Paulinas, 2011. 
CORREIA, C. J. "A Identidade Narrativa e o Problema da Identidade Pessoal”. Arquipélago 7 (2000), pp. 177-194.

DE LA CALLE, F. A teologia do quarto evangelho. São Paulo: Paulinas, 1985.

GARCIA MARQUEZ, G. Vivir para contarla, Barcelona: Mondadori, 2002.

GESCHÉ, A. "Pour une identité narrative de Jésus". RTL 30/2 (1999), pp. 153-179.

GESCHÉ, A. "Pour une identité narrative de Jésus". RTL 30/3 (1999), pp. 336-356.

GESCHÉ, A. O Cristo. Coleção Deus para pensar VI. São Paulo: Paulinas, 2004. GRENZER, M. O projeto do Exodo. São Paulo: Paulinas, 2004.

JEREMIAS, J. As parábolas de Jesus. 11ª . Ed. São Paulo: Paulus, 2016.

MANZATTO, A. “O Messias do texto”. Ciberteologia 36 (2011), pp. 5-22.

PAGOLA, J. A. Jesus, aproximação histórica. Petrópolis: Vozes, 2010.

PAPA FRANCISCO, Evangelii Gaudium. Brasília: Ed. CNBB, 2013.

RICOEUR, P. “L'identité narrative”. Esprit 7/8 (1988), pp. 295-304.

RICOEUR, P. "L'identité narrative". BÜHLER, P.; HABERMACHER, J.F. (Eds.). La narration. Quand le récit devient communication. Genebra: Labor et Fides, 1988, pp. 287-300.

RICOEUR, P. A hermenêutica bíblica. São Paulo: Loyola, 2006.

RICOEUR, P. Temps et récit III. Le temps raconté. Paris: Seuil, 1985.

Antonio Manzatto

Doutor em Teologia pela Faculdade de Teologia da Universidade Católica de Lovaina (Bélgica) Professor titular do Departamento de Teologia Sistemática da Pontifícia Universidade Católica de São Paulo

São Paulo / SP - Brasil E-mail: amanzatto@pucsp.br

Recebido em: 28/08/17

Aprovado em: 27/11/17 